\title{
KARAKTERISTIK FISIK, SENSORI, SERTA AKTIVITAS ANTIOKSIDAN ROTI GANDUM DENGAN TAMBAHAN SERBUK TEH HIJAU
}

\section{Physical, Sensory Characteristics, and Antioxidant Activity of Wheat Bread with Green Tea Powder Addition}

\author{
Monika Rahardjo $^{1 *}$, Franzesca Dwi Wahyu², Erfina Trivena Nadia ${ }^{2}$
}

1) Program Studi Teknologi Pangan, FKIK Universitas Kristen Satya Wacana Salatiga

Jl. Diponegoro no. 52-60, Salatiga 50711

2) Program Studi Gizi, FKIK Universitas Kristen Satya Wacana Salatiga

Jl. Diponegoro no. 52-60, Salatiga 50711

*Penulis Korespondensi, Email: monika.rahardjo@uksw.edu

\begin{abstract}
ABSTRAK
Tujuan penelitian ini adalah untuk mengetahui karakteristik fisik, sensori, serta aktivitas antioksidan roti gandum dengan tambahan serbuk teh hijau. Digunakan lima formulasi dalam penelitian ini yang terdiri dari penambahan serbuk teh hijau dengan konsentrasi berbeda yaitu F1 (1\%), F2 (2\%), F3 (3\%), F4 (4\%), dan F5 (5\%). Hasil uji tekstur menunjukkan bahwa terdapat perbedaan yang signifikan pada karakteristik fisik roti gandum dengan penambahan serbuk teh hijau untuk parameter tingkat kekerasan, kekenyalan, fraktur, daya rekat, dan kekakuan $(\alpha=5 \%)$. Untuk parameter warna, penambahan serbuk teh hijau dalam formulasi roti gandum menunjukkan penurunan nilai $L$ dan $a^{*}$, sedangkan nilai $b^{*}$ meningkat secara signifikan $(\alpha=5 \%)$. Evaluasi sensori tidak menunjukkan perbedaan signifikan pada parameter tekstur, warna, rasa, dan keseluruhan. Uji aktivitas antioksidan menunjukkan bahwa penambahan serbuk teh hijau pada formulasi roti gandum berefek signifikan pada peningkatan aktivitas antioksidan.
\end{abstract}

Kata kunci: Aktivitas antioksidan, Roti gandum, Sifat fisik, Sensori, Serbuk teh hijau

\section{ABSTRACT}

The purpose of this research was to determine the physical and sensory characteristics and also antioxidant activity of wheat bread with green tea powder addition. Five formulations used in this research consist of the green tea powder addition namely F1 (1\%), F2 (2\%), F3 (3\%), F4 (4\%), and F5 (5\%). The texture analysis showed that the physical characteristics had significance difference for hardness, gumminess, fracture, adhesiveness, and stiffness from wheat bread with green tea powder addition ( $\alpha=5 \%)$. For color analysis, increasing green tea powder addition in the wheat bread formulations showed decreasing in $L$ and $a^{*}$ values, while $b^{*}$ values increased significantly $(\alpha=5 \%)$. Sensory evaluation showed no significance difference for texture, color, taste, and overall parameters, however F4 showed the highest acceptance rating for overall parameter. For antioxidant activity, the result showed that the addition of green tea powder to wheat bread had a significant effect on increasing antioxidant activity.

Keywords: Antioxidant activity, Green tea powder, Physical characteristic, Sensory, Wheat bread

\section{PENDAHULUAN}

Teh (Camellia sinensis L.), terutama jenis teh hijau, banyak dikonsumsi sebagai minuman terutama di negara Jepang dan China karena manfaat kesehatannya. Teh hijau sendiri mempunyai kandungan utama yang disebut katekin, yang merupakan senyawa 
polifenol utama pada teh hijau (Phongnarisorn et al., 2018). Katekin pada daun hijau terdiri dari epikatekin (EK), epigalokatekin (EGK), epigalokatekin galat (EGKG), dan epikatekin galat (EKG) yang memberikan rasa astringent dan pahit pada seduhan teh (Chen et al., 2009).

Teh hijau merupakan teh yang diproduksi dengan cara mengeringkan daunnya sesegera mungkin untuk mempertahankan sebagian besar kandungan katekin di dalamnya, sedangkan teh hitam merupakan teh yang telah melalui proses oksidasi enzimatis, sehingga sebagian besar katekinnya telah teroksidasi menjadi teaflavin, tearubigin, dan oligomeroligomer lainnya (Balentine et al., 1997 dan Graham, 1992 dalam Lee et al., 2014). Konsumsi teh mempunyai dampak positif bagi kesehatan karena kandungan antioksidannya yang dapat mencegah kanker, penyakit-penyakit kardiovaskular, diabetes (Sharangi, 2009), memperlancar pencernaan dan membantu proses transformasi lemak (Basu \& Lucas, 2007). Selain penelitian yang telah dilakukan pada konsumen berkaitan dengan meningkatnya konsumsi teh hijau karena manfaat kesehatannya (Kim et al., 2013; Mennen et al., 2007), terdapat penelitian lain yang menunjukkan bahwa terjadi peningkatan keinginan konsumen untuk produk-produk convenience yang dilengkapi komponen nilai tambah yang lain, seperti antioksidan (Carrillo et al., 2012; Šebečić et al., 2007). Roti gandum termasuk dalam kategori produk convenience yang sudah umum dikonsumsi oleh masyarakat Indonesia dan diprediksi akan terus mengalami peningkatan jumlah konsumsinya sampai tahun 2030 (Elliott et al., 2019).

Penambahan serbuk teh hijau ke dalam produk bakery juga bisa berfungsi untuk menutupi rasa pahit dan sepat yang biasanya menjadi dominansi rasa teh hijau (Phongnarisorn et al., 2018). Penelitian sebelumnya menunjukkan juga bahwa penambahan serbuk teh hijau ke dalam produk cookies, mie, dan cake yang adonannya dibuat dengan tepung gandum, menunjukkan efek pada sifat-sifat fisikokimia, warna, tekstur, serta umur simpan (Ahmad et al., 2015; Li et al., 2012; Lu et al., 2010), namun belum tersedia penelitian untuk roti gandum. Penelitian sebelumnya juga menunjukkan bahwa secara sensori produk cakes dengan tepung gandum yang ditambahkan $20 \%$ serbuk teh hijau memperoleh tingkat penerimaan yang bagus oleh konsumen (Lu et al., 2010). Oleh sebab itu, penelitian ini bertujuan untuk mengetahui efek penambahan serbuk teh hijau pada karakteristik fisik, sensori, serta aktivitas antioksidan roti gandum.

\section{BAHAN DAN METODE}

\section{Bahan}

Bahan baku pembuat roti gandum adalah tepung gandum utuh yang dibeli dari Fakultas Pertanian dan Bisnis UKSW, serbuk teh hijau merk Tacha, ragi roti merk Fermipan, dan bahanbahan lain untuk membuat roti tawar. Bahan kimia yang digunakan adalah DPPH merk Sigma.

Alat

Alat yang akan di gunakan yaitu standing mixer (Turbo Mixer Grande Ehm 9595), proofer (Astro BFR-05), oven (KIRIN Oven Toaster KBO-360LW), chromameter (Konika Minolta CR400), texture analyzer (Lloyd TA Plus).

\section{Desain Penelitian}

Pembuatan roti gandum serta pengujian sensori dilakukan di Laboratorium Food Processing dan Laboratorium Sensori Fakultas Kedokteran dan IImu Kesehatan UKSW., pengujian aktivitas antioksidan dilakukan di Laboratorium Kimia Fakultas Sains dan Matematika UKSW, sedangkan pengujian warna dan fisik dilakukan di Laboratorium Fakultas Teknologi Pertanian Unika Soegijapranata. Bahan formulasi roti gandum dapat dilihat pada Tabel 1 dan rancangan penelitian dapat dilihat pada Tabel 2. 


\begin{tabular}{lc}
$\begin{array}{c}\text { Tabel 1. Bahan Formulasi Roti Gandum } \\
\text { Jenis Bahan }\end{array}$ & Berat (g) \\
\hline \multicolumn{2}{c}{ Prefermented Dough } \\
\hline Tepung gandum & 115 \\
Air & 85 \\
Yeast instant & 2 \\
Garam & 3.5 \\
\hline \multicolumn{2}{c}{ Roti Gandum } \\
\hline Tepung gandum & 385 \\
Air & 240 \\
Garam & 7 \\
Yeast instant & 3.5 \\
Gula & 18 \\
Mentega & 40 \\
Susu bubuk & 18 \\
Prefermented dough & 191 \\
\hline
\end{tabular}

Persentase penambahan serbuk teh hijau dihitung dari total berat tepung gandum yang digunakan pada formulasi roti tawar gandum.

Tabel 2. Rancangan Penelitian Penambahan Serbuk Teh Hijau pada Adonan Roti Gandum

\begin{tabular}{cl}
\hline $\begin{array}{c}\text { Konsentrasi Penambahan } \\
\text { Serbuk Teh Hijau (\%) }\end{array}$ & Kode \\
\hline $0 \%$ & Kontrol \\
$1 \%$ & $\mathrm{~F} 1$ \\
$2 \%$ & $\mathrm{~F} 2$ \\
$3 \%$ & $\mathrm{~F} 3$ \\
$4 \%$ & $\mathrm{~F} 4$ \\
$5 \%$ & $\mathrm{~F} 5$ \\
\hline
\end{tabular}

\section{Tahapan Penelitian}

Mula-mula adonan roti gandum dibuat dengan menggunakan penambahan green tea extract powder sesuai dengan rancangan penelitian pada Tabel 1. Setelah itu, pada roti gandum yang telah jadi, dilakukan uji warna dan analisis fisik dan selanjutnya dilakukan uji sensori.

\section{Metode \\ Pembuatan Roti Gandum}

Bahan dan metode pembuatan roti gandum merujuk pada Suas (2009). Pertama-tama pre-fermented dough dibuat dengan cara mencampurkan semua bahan dan dibiarkan terfermentasi selama satu jam pada temperatur ruang. Pre-fermented dough ini nantinya dicampurkan ke dalam adonan roti gandum. Bahan-bahan roti gandum kemudian disiapkan dan dicampurkan menggunakan kecepatan sedang menggunakan standing mixer sampai konsistensi sedang tercapai. Pengecekan konsistensi adonan dilakukan dengan cara mengambil sedikit adonan, melebarkannya sampai adonan tembus cahaya, yang artinya dalam adonan roti tersebut gluten sudah terbentuk dengan baik. Adonan roti kemudian dibiarkan terfermentasi pertama selama 45 menit, setelah itu adonan dibagi-bagi seberat 500 $\mathrm{g}$, dibentuk bola. Adonan dimasukkan ke dalam loyang, kemudian dibiarkan beristirahat selama 25 menit sebelum dimasukkan ke dalam proofer. Selanjutnya, di dalam proofer, adonan dibiarkan selama 1 jam 30 menit pada temperatur $27{ }^{\circ} \mathrm{C}$ dengan $\mathrm{RH} 65 \%$. Tahap terakhir, adonan roti kemudian dipanggang dalam oven selama 35 menit pada temperatur 196 ${ }^{0} \mathrm{C}$. 


\section{Prosedur Analisis \\ Analisis Warna}

Pengujian warna dilakukan pada bagian crumb dan bagian dalam roti. Pengujian warna dilakukan menggunakan chromameter, chromameter sebelumnya dikalibrasi terlebih dahulu menggunakan standar warna putih yang terdapat pada alat tersebut. Hasil analisis warna berupa nilai $\mathrm{L}$ (tingkat kecerahan), $\mathrm{a}^{*}$ (tingkat warna merah ke hijau, nilai positif ke negatif berturut-turut), $b^{*}$ (tingkat wana kuning ke biru, nilai positif ke negatif berturut-turut) (Altindag et al., 2015).

\section{Analisis Fisik}

Analisis fisik yang dilakukan pada roti adalah berat roti (menggunakan neraca analitik), volume, analisis moisture, dan analisis tekstur (Krupa-Kozak et al., 2012). Analisis tekstur akan dilakukan menggunakan texture analyzer sehingga akan diperoleh data hardness, springiness, cohesiveness, dan chewiness. Masing-masing perlakuan diambil data dari tiga sampel sehinga bisa dihitung rata-rata dan standar deviasinya.

\section{Analisis Sensori}

Roti gandum diuji sifat-sifat sensorinya menggunakan panelis yang tidak terlatih sebanyak 35 orang dengan menggunakan uji hedonik dengan sistem 5 skala ( 1 = sangat tidak suka, 5 = sangat suka). Parameter sensori yang diuji terdiri dari visual warna, aroma, rasa, tekstur, dan penerimaan secara overall (Krupa-Kozak et al., 2011; Krupa-Kozak et al., 2012).

\section{Analisis Aktivitas Antioksidan}

Analisis aktivitas antioksidan pada masing-masing roti gandum dilakukan menggunakan metode DPPH (Bajerska et al., 2010).

\section{Analisis Statistik}

Keseluruhan data selanjutnya dianalisis dengan perhitungan ANOVA (Analysis of Variance) pada $\alpha=5 \%$ untuk mengetahui adanya perbedaan nyata pada setiap parameter uji. Apabila menunjukkan perbedaan nyata, maka perhitungan statistik dilanjutkan dengan uji Duncan's Multiple Range Test (DMRT) pada $\alpha=5 \%$ untuk menentukan tingkat perlakuan yang memberikan perbedaan nyata (Altindag et al., 2015).

\section{HASIL DAN PEMBAHASAN}

\section{Karakteristik Fisik}

Serbuk teh hijau yang digunakan merupakan serbuk yang halus, larut air, dan berwarna hijau. Perbandingan karakteristik tekstur serta warna dari kontrol dan roti gandum yang sudah ditambahkan serbuk teh hijau dapat dilihat berturut-turut pada Tabel 3 dan Tabel 4. Hasil uji tekstur untuk parameter cohesiveness, springiness, dan chewiness tidak ditampilkan dalam tabel karena tidak berpengaruh secara signifikan. Analisis varian menunjukkan bahwa terdapat pengaruh signifikan dari penambahan serbuk teh hijau pada adonan roti gandum pada tingkat hardness, gumminess, fracture, adhesiveness, dan stiffness dari roti gandum.

Hardness merupakan salah satu karakteristik roti yang penting, yang biasanya digunakan untuk menentukan kualitas dari roti. Perubahan hardness biasanya disebabkan karena hilangnya resiliensi saat penyimpanan (Spies, 1990). Hasil penelitian menunjukkan bahwa hardness dari roti gandum semakin bertambah seiring semakin banyaknya persentase serbuk teh hijau yang ditambahkan dalam formulasi adonan roti. Hasil uji Duncan menunjukkan bahwa roti gandum yang hardness-nya berbeda signifikan dibandingkan kontrol adalah pada roti gandum Formulasi 5.

Matriks roti merupakan sistem yang kompleks, oleh karena itu sampai saat ini, mekanisme yang berperan pada peningkatan hardness roti dengan variasi penambahan 
serbuk teh hijau masih belum banyak diketahui (Wang et al., 2007). Variasi perubahan hardness pada roti gandum dengan penambahan serbuk teh hijau kemungkinan juga dipengaruhi oleh aktivitas enzim serta ragi yang digunakan saat proses pengolahan. Zhang dan Kashket (1998) melaporkan bahwa polifenol yang terkandung dalam teh hijau dapat menurunkan aktivitas enzim amilase dalam air liur manusia, ditunjukkan dengan berkurangnya produksi maltosa yang umumnya dilihat sebagai indikator dari aktivitas amilase. Sehingga, penambahan serbuk teh hijau dalam adonan roti juga kemungkinan menghambat aktivitas amilase sehingga menyebabkan kurangnya maltosa yang berfungsi untuk mendukung aktivitas ragi selama proses pengembangan roti (proofing). Aktivitas ragi yang berkurang menyebabkan turunnya jumlah gas yang terbentuk selama proses fermentasi dan menyebabkan volume roti berkurang dengan tekstur yang keras dan padat.

Gumminess merupakan hasil perkalian antara parameter firmness dan cohesiveness. Firmness didefinisikan sebagai kekuatan bertahan dari kompresi yang dilakukan pada produk, sedangkan cohesiveness didefinisikan sebagai seberapa baik produk dapat bertahan pada deformasi kedua relatif pada deformasi pertama (Wang et al., 2006). Pada penelitian ini, tingkat gumminess pada roti gandum yang ditambahkan serbuk teh hijau berbeda signifikan berdasarkan hasil analisis varian, di mana roti gandum Formulasi 5 mempunyai perbedaan yang signifikan dibandingkan kontrol. Peningkatan gumminess pada roti gandum di penelitian ini kemungkinan disebabkan karena adanya senyawa glutelin yang terkandung dalam teh hijau (Shen et al., 2008). Glutelin dari teh hijau ini kemudian bercampur dengan prolamin dalam tepung gandum untuk membuat jaringan dan memperkuat struktur adonan, namun sampai batas tertentu, yang nantinya justru akan melemahkan matriks gluten dan menurunkan kualitas roti (Wang et al., 2007).

Adhesiveness merupakan daya yang dibutuhkan untuk menarik produk dari permukaannya, nilainya diperoleh dari area yang berada diantara area kompresi pertama dan kedua. Semakin besar nilai adhesiveness berarti produk pangan semakin cenderung tidak menghasilkan sifat lengket (sticky). Pada penelitian ini, penambahan serbuk teh hijau secara signifikan menyebabkan peningkatkan nilai adhesiveness pada roti gandum. Peningkatan adhesiveness ini disebabkan karena senyawa yang mengandung gugus hidroksil yang terkandung pada teh hijau, yaitu polifenol dan polisakarida. Penelitian dari Zhou et al. (2009) senyawa hidroksil mempengaruhi kekuatan adonan, dimana semakin tinggi kandungannya akan melemahkan matriks gluten dan membuat adonan menjadi tidak stabil. Akibat ketidakstabilan adonan menyebabkan roti bertekstur lebih keras dan tidak mengembang.

Tabel 3. Hasil Uji Tekstur pada Roti Gandum dengan Penambahan Serbuk Teh Hijau

\begin{tabular}{cccccc}
\hline Formulasi & Hardness (gf) & $\begin{array}{c}\text { Gumminess } \\
\text { (kgf) }\end{array}$ & $\begin{array}{c}\text { Fracture } \\
\text { Force (kgf) }\end{array}$ & $\begin{array}{c}\text { Adhesiveness } \\
\text { Force (kgf) }\end{array}$ & Stiffness (gf/cm) \\
\hline Kontrol & $251.34 \pm 127.36^{1}$ & $0.01 \pm 0.00^{1}$ & $0.00 \pm 0.00^{1}$ & $0.01 \pm 0.00^{1}$ & $1072.13 \pm 390.92^{1}$ \\
Formulasi 1 & $398.39 \pm 152.58^{1}$ & $0.03 \pm 0.01^{1,2}$ & $0.01 \pm 0.00^{1}$ & $0.03 \pm 0.01^{1,2}$ & $1430.94 \pm 366.37^{1}$ \\
Formulasi 2 & $449.13 \pm 127.50^{1}$ & $0.03 \pm 0.02^{1,2}$ & $0.01 \pm 0.00^{1,2}$ & $0.03 \pm 0.01^{1}$ & $1589.32 \pm 324.00^{1}$ \\
Formulasi 3 & $659.13 \pm 57.47^{1}$ & $0.02 \pm 0.01^{1}$ & $0.02 \pm 0.00^{1}$ & $0.04 \pm 0.01^{1}$ & $1637 \pm 166.98^{1}$ \\
Formulasi 4 & $886.66 \pm 157.12^{1}$ & $0.02 \pm 0.01^{1,2}$ & $0.02 \pm 0.00^{1,2}$ & $0.04 \pm 0.01^{1,2}$ & $1781.62 \pm 399.35^{1}$ \\
Formulasi 5 & $1079.95 \pm 381.34^{2}$ & $0.05 \pm 0.04^{2}$ & $0.03 \pm 0.01^{2}$ & $0.04 \pm 0.02^{2}$ & $2774.90 \pm 312.59^{2}$ \\
\hline
\end{tabular}

Keterangan: Angka superscript yang berbeda yang terdapat pada kolom yang sama menunjukkan adanya perbedaan yang signifikan $(\alpha=5 \%)$

Stiffness didefinisikan sebagai kemampuan untuk menerima kompresi tanpa menyebabkan terjadinya deformasi. Dapat dilihat pada Tabel 1, tingkat stiffness dari roti gandum meningkat seiring penambahan persentase serbuk teh hijau dalam adonan roti. Hasil analisis varian juga menunjukkan bahwa penambahan serbuk teh hijau berpengaruh signifikan pada tingkat stiffness roti gandum. Stiffness roti gandum seiring penambahan serbuk teh hijau kemungkinan disebabkan oleh kandungan dari teh hijau, yaitu senyawa fenolik dan antioksidan yang interaksinya berefek pada kualitas roti (Wang et al., 2006). Wang dan Zhou (2004) melaporkan bahwa terdapat kemungkinan interaksi antara senyawa fenolik dengan 
protein gandum lewat ikatan hidrogen selama proses penyiapan adonan saat ditambahkan serbuk teh hijau. Peningkatan selulosa pada adonan akan menyebabkan penurunan daya absorpsi air pada adonan yang menyebabkan kandungan air untuk pembentukan kurang dan sifat viskoelastis roti menjadi tidak baik dan menjadi kaku (Sivam et al., 2010). Dilihat dari hasil uji tekstur, tingkat stiffness berkaitan dengan fracture, di mana semakin meningkat nilai stiffness nilai fracture juga semakin meningkat.

Warna merupakan salah satu faktor yang mempengaruhi tingkat penerimaan konsumen. Pendeteksian warna secara kuantitatif dilakukan menggunakan chromameter untuk memperoleh nilai tingkat kecerahan $(L)$, nilai rona warna merah $\left(a^{*}\right)$ dan nilai rona warna kuning $\left(b^{*}\right)$ pada sampel roti. Dari hasil uji chromameter untuk mengidentifikasi warna dari roti gandum seperti yang dapat dilihat pada Tabel 2 , terlihat terjadi penurunan nilai $L$, penurunan $a^{*}$, serta kenaikan nilai $b^{*}$ secara signifikan antara kontrol serta formulasi roti gandum yang lain. Analisis varian (ANOVA) membuktikan bahwa hal ini disebabkan karena semakin banyaknya persentase serbuk teh hijau yang digunakan dalam formulasi pembuatan roti gandum.

Tabel 4. Hasil Uji Warna pada Roti Gandum dengan Penambahan Serbuk Teh Hijau

\begin{tabular}{cccc}
\hline Formulasi & $\mathbf{L}$ & $\mathbf{a}^{\star}$ & $\mathbf{b}^{\star}$ \\
\hline Kontrol & $48.23 \pm 2.11^{3}$ & $5.28 \pm 0.50^{4}$ & $21.89 \pm 0.70^{2}$ \\
F1 & $40.89 \pm 0.34^{2}$ & $2.93 \pm 0.19^{3}$ & $19.59 \pm 0.58^{1}$ \\
F2 & $40.07 \pm 2.42^{1,2}$ & $2.29 \pm 0.22^{2}$ & $19.83 \pm 0.74^{2}$ \\
F3 & $36.04 \pm 2.41^{1}$ & $2.01 \pm 0.13^{2}$ & $19.89 \pm 0.96^{1}$ \\
F4 & $35.46 \pm 6.41^{1}$ & $1.80 \pm 0.62^{2}$ & $20.77 \pm 0.93^{1,2}$ \\
F5 & $34.03 \pm 2.59^{1,2}$ & $1.06 \pm 0.22^{1}$ & $20.83 \pm 0.20^{1,2}$ \\
\hline
\end{tabular}

Keterangan: Angka superscript yang berbeda yang terdapat pada kolom yang sama menunjukkan adanya perbedaan yang signifikan ( $\alpha=5 \%)$

Tingkat kecerahan dari roti dipengaruhi oleh senyawa-senyawa berwarna coklat yang dihasilkan dari proses oksidasi katekin menjadi teaflavin, tearubigin, dan teabrownin pada saat proses baking dengan temperatur tinggi (Ning et al. 2017). Keberadaan protein (telur dan susu) dan gula yang cukup tinggi pada bahan adonan roti mempengaruhi tingkat kecerahan karena berefek pada reaksi Maillard dan karamelisasi saat proses baking (Adiluhung dan Sutrisno, 2018; Harzau dan Estiasih, 2013). Selain itu teh hijau yang juga mengandung senyawa klorofil, terdegradasi dan menghasilkan magnesium klorofil yang juga berwarna coklat (Wan, 2007 dalam Ning et al., 2017).

\section{Karakteristik Sensori dan Aktivitas Antioksidan}

Data hasil uji sensori pada 35 panelis tidak terlatih menggunakan uji hedonik rating kesukaan 5 skala dapat dilihat pada Tabel 5. Perhitungan ANOVA untuk data sensori yang diperoleh pada empat parameter uji menunjukkan bahwa tidak terdapat perbedaan yang signifikan dengan penambahan persentase serbuk teh hijau pada roti gandum. Rating tertinggi secara overall diperoleh roti gandum Formulasi 4.

Tabel 5. Hasil Uji Sensori Penerimaan Rating Kesukaan

\begin{tabular}{ccccc}
\hline Formulasi & Tekstur & Warna & Rasa & Overall \\
\hline Kontrol & $3.17 \pm 0.61$ & $3.04 \pm 0.75$ & $3.18 \pm 0.71$ & $3.25 \pm 0.97$ \\
F1 & $3.23 \pm 0.97$ & $3.14 \pm 0.97$ & $3.71 \pm 1.13$ & $3.57 \pm 0.92$ \\
F2 & $3.49 \pm 1.10$ & $3.26 \pm 1.07$ & $3.59 \pm 1.17$ & $3.51 \pm 0.95$ \\
F3 & $3.54 \pm 1.22$ & $3.31 \pm 1.11$ & $3.77 \pm 1.24$ & $3.57 \pm 1.15$ \\
F4 & $3.57 \pm 1.22$ & $3.54 \pm 1.07$ & $3.66 \pm 1.37$ & $3.83 \pm 0.99$ \\
F5 & $3.49 \pm 1.25$ & $3.57 \pm 1.07$ & $3.72 \pm 1.06$ & $3.63 \pm 1.09$ \\
\hline
\end{tabular}


Aktivitas antioksidan dari roti gandum pada penelitian ini dianalisis menggunakan metode DPPH. Hasil dari uji DPPH dalam bentuk \% inhibisi dapat dilihat pada Tabel 6, di mana penambahan serbuk teh hijau pada adonan roti gandum menunjukkan pengaruh signifikan pada aktivitas antioksidan. Semakin besar persentase serbuk teh hijau yang ditambahkan dalam adonan roti menunjukkan aktivitas antioksidan yang semakin besar. Penelitian Komes et al. (2010) menunjukkan bahwa teh hijau mempunyai aktivitas antioksidan yang signifikan, mengkonfirmasi bahwa teh hijau merupakan salah satu sumber antioksidan terbaik. Selain itu, penelitian yang dilakukan oleh Ning et al. (2017) juga menunjukkan hasil yang serupa.

Tabel 6. Hasil Uji Aktivitas Antioksidan Roti Gandum dengan Penambahan Serbuk Teh Hijau

\begin{tabular}{lc}
\hline Formulasi & Aktivitas Antioksidan (\% \\
\hline Kontrol & $3.34 \pm 0.15^{1}$ \\
F1 & $25.69 \pm 0.66^{2}$ \\
F2 & $56.82 \pm 1.52^{3}$ \\
F3 & $59.72 \pm 1.25^{4}$ \\
F4 & $66.69 \pm 2.86^{5}$ \\
F5 & $91.41 \pm 1.69^{6}$
\end{tabular}

Keterangan: Angka superscript yang berbeda yang terdapat pada kolom yang sama menunjukkan adanya perbedaan yang signifikan $(\alpha=5 \%)$

Penelitian Mildner-Szkudlarz et al. (2009) menunjukkan bahwa serbuk teh hijau mempunyai efek antioksidan yang berfungsi untuk menstabilkan lemak pada biskuit serta dapat menginhibisi pembentukan hidroperoksida hingga sekitar $47-73 \%$. Namun, kapasitas antioksidan dari katekin, salah satu senyawa antioksidan yang terkandung dalam teh, berkurang disebabkan karena proses baking roti yang umumnya menggunakan temperatur tinggi sehingga katekin teroksidasi. Untuk menjaga kapasitas antioksidan dalam serbuk teh hijau, teknologi mikroenkapsulasi dapat dipertimbangkan pada saat digunakan dalam pengolahan produk bakery (Pasrija et al. 2015).

\section{SIMPULAN}

Hasil penelitian menunjukkan bahwa penambahan serbuk teh hijau pada roti gandum mempengaruhi karakteristik fisik, sensori, serta aktivitas antioksidan dari roti gandum. Perbedaan signifikan ditunjukkan pada karakteristik fisik roti gandum untuk parameter tingkat kekerasan, kekenyalan, fraktur, daya rekat dan kekakuan pada $\alpha=5 \%$. Penambahan serbuk teh hijau juga mempengaruhi parameter warna dari roti gandum meliputi penurunan nilai $L$ dan $a^{*}$, serta peningkatan nilai $b^{*}$ secara signifikan pada $\alpha=5 \%$. Hasil evaluasi sensori dari roti gandum yang telah ditambahkan serbuk teh hijau pada adonannya tidak menunjukkan perbedaan signifikan pada parameter tekstur, warna, rasa, dan keseluruhan. Uji aktivitas antioksidan pada roti gandum dengan penambahan serbuk teh hijau menunjukkan efek yang signifikan pada peningkatan aktivitas antioksidannya.

\section{DAFTAR PUSTAKA}

Adiluhung, W. D., \& Sutrisno, A. (2018). Pengaruh konsentrasi glukomannan dan waktu proofing terhadap karakteristik tekstur dan organoleptik roti tawar beras (Oriza sativa) bebas gluten. Jurnal Pangan dan Agroindustri, 6(4), 26-37.

Ahmad, M., Baba, W. N., A.Wani, T., Gani, A., Gani, A., Shah, U., ... Masoodi, F. A. (2015). Effect of green tea powder on thermal, rheological \& functional properties of wheat flour and physical, nutraceutical \& sensory analysis of cookies. Journal of Food Science and Technology, 52(9), 5799-5807. https://doi.org/10.1007/s13197-014-1701-3

Altindag, G., Certel, M., Erem, F., \& Ilknur Konak, Ü. (2015). Quality characteristics of glutenfree cookies made of buckwheat, corn, and rice flour with/without transglutaminase. 
Food Science and Technology International, 21(3), 213-220. https://doi.org/10.1177/1082013214525428

Bajerska, J., Mildner-Szkudlarz, S., Jeszka, J., \& Szwengiel, A. (2010). Catechin stability, antioxidant properties and sensory profiles of rye breads fortified with green tea extracts. Journal of Food and Nutrition Research, 49(2), 104-111.

Basu, A., \& Lucas, E. a. (2007). Mechanisms and effects of green tea on cardiovascular health. Nutr Rev, 65(8 Pt 1), 361-375. https://doi.org/10.1301/nr.2007.aug.361

Carrillo, E., Varela, P., \& Fiszman, S. (2012). Effects of food package information and sensory characteristics on the perception of healthiness and the acceptability of enriched biscuits. Food Research International, 48(1), 209-216. https://doi.org/10.1016/j.foodres.2012.03.016

Chen, Q., Zhao, J., Chaitep, S., \& Guo, Z. (2009). Simultaneous analysis of main catechins contents in green tea (Camellia sinensis (L.)) by Fourier transform near infrared reflectance (FT-NIR) spectroscopy. Food Chemistry, 113(4), 1272-1277. https://doi.org/10.1016/j.foodchem.2008.08.042

Elliott, P., Kingwell, R., \& Carter, C. (2019). The growing consumption of bread and baked goods in Indonesia. Australia.

Harzau, H., \& Estiasih, T. (2013). Karakteristik cookies umbi inferior uwi putih (kajian proporsi tepung uwi : pati jagung dan penambahan margarin).Jurnal Pangan dan Agroindustri, 1(1), 138-147.

Kim, Y. K., Jombart, L., Valentin, D., \& Kim, K. O. (2013). A cross-cultural study using Napping $\AA^{8}$ : Do Korean and French consumers perceive various green tea products differently? Food Research International, 53(1), 534-542. https://doi.org/10.1016/j.foodres.2013.05.015

Komes, D., Horžić, D., Belščak, A., Ganić, K. K., \& Vulić, I. (2010). Green tea preparation and its influence on the content of bioactive compounds. Food Research International, 43(1), 167-176. https://doi.org/10.1016/j.foodres.2009.09.022

Krupa-Kozak, U., Agnieszka, T., Natalia, B., \& Soral-Smietana, M. (2011). Effect of organic calcium supplememts on the technological characteristic and sensory properties of gluten-free bread. European Food Research and Technology, 232(3), 497-508.

Krupa-Kozak, U., Altamirano-Fortoul, R., Wronkowska, M., \& Rosell, C. M. (2012). Breadmaking performance and technological characteristic of gluten-free bread with inulin supplemented with calcium salts. European Food Research and Technology. https://doi.org/10.1007/s00217-012-1782-z

Lee, M. S., Hwang, Y. S., Lee, J., \& Choung, M. G. (2014). The characterization of caffeine and nine individual catechins in the leaves of green tea (Camellia sinensis L.) by nearinfrared reflectance spectroscopy. Food Chemistry, 158, 351-357. https://doi.org/10.1016/j.foodchem.2014.02.127

Li, M., Zhang, J. H., Zhu, K. X., Peng, W., Zhang, S. K., Wang, B., ... Zhou, H. M. (2012). Effect of superfine green tea powder on the thermodynamic, rheological and fresh noodle making properties of wheat flour. LWT - Food Science and Technology, 46(1), 23-28. https://doi.org/10.1016/j.lwt.2011.11.005

Lu, T. M., Lee, C. C., Mau, J. L., \& Lin, S. D. (2010). Quality and antioxidant property of green tea sponge cake. Food Chemistry, 119(3), 1090-1095. https://doi.org/10.1016/j.foodchem.2009.08.015

Mennen, L., Hirvonen, T., Arnault, N., Bertrais, S., Galan, P., \& Hercberg, S. (2007). Consumption of black, green and herbal tea and iron status in French adults. European Journal of Clinical Nutrition, 61(10), 1174-1179. https://doi.org/10.1038/sj.ejcn.1602634

Mildner-Szkudlarz, S., Zawirska-Wojtasiak, R., Obuchowski, W., \& Gośliński, M. (2009). Evaluation of Antioxidant Activity of Green Tea Extract and Its Effect on the Biscuits Lipid Fraction Oxidative Stability. Journal of Food Science, 74(8), S362-S370. https://doi.org/10.1111/j.1750-3841.2009.01313.x 
Ning, J., Hou, G. G., Sun, J., Wan, X., \& Dubat, A. (2017). Effect of green tea powder on the quality attributes and antioxidant activity of whole-wheat flour pan bread. LWT - Food Science and Technology, 79, 342-348. https://doi.org/10.1016/j.Iwt.2017.01.052

Pasrija, D., Ezhilarasi, P. N., Indrani, D., \& Anandharamakrishnan, C. (2015). Microencapsulation of green tea polyphenols and its effect on incorporated bread quality. LWT - Food Science and Technology, 64(1), 289-296. https://doi.org/10.1016/j.lwt.2015.05.054

Phongnarisorn, B., Orfila, C., Holmes, M., \& Marshall, L. J. (2018). Enrichment of biscuits with matcha green tea powder: Its impact on consumer acceptability and acute metabolic response. Foods, 7(2). https://doi.org/10.3390/foods7020017

Šebečić, B., Dragojević, I. V., Čepo, D. V., \& Marijana, H. (2007). Raw Materials in Fibre Enriched Biscuits Production as Source of Total Phenols. Retrieved December 4, 2019, from

https://www.researchgate.net/publication/26485822_Raw_Materials_in_Fibre_Enriche d_Biscuits_Production_as_Source_of_Total_Phenols

Sharangi, A. B. (2009). Medicinal and therapeutic potentialities of tea (Camellia sinensis L.) A review. Food Research International, 42(5-6), 529-535. https://doi.org/10.1016/j.foodres.2009.01.007

Shen, L., Wang, X., Wang, Z., Wu, Y., \& Chen, J. (2008). Studies on tea protein extraction using alkaline and enzyme methods. Food Chemistry, 107(2), 929-938. https://doi.org/10.1016/j.foodchem.2007.08.047

Sivam, A. S., Sun-Waterhouse, D., Quek, S. Y., \& Perera, C. O. (2010). Properties of bread dough with added fiber polysaccharides and phenolic antioxidants: A review. Journal of Food Science, 75(8). https://doi.org/10.1111/j.1750-3841.2010.01815.x

Spies, R. (1990). Application of Rheology in the Bread Industry. In Dough Rheology and Baked Product Texture (pp. 343-361). Springer US. https://doi.org/10.1007/978-1-4613-08614_7

Suas, M. (2009). Advanced bread and pastry: a professional approach. Delmar Cengage Learning.

https://books.google.co.id/books/about/Advanced_Bread_and_Pastry.html?id=JM76v m5tH38C\&redir_esc $=y$

Wang, R., \& Zhou, W. (2004). Stability of Tea Catechins in the Breadmaking Process. Journal of Agricultural and Food Chemistry, 52(26), 8224-8229. https://doi.org/10.1021/jf048655x

Wang, R., Zhou, W., \& Isabelle, M. (2007). Comparison study of the effect of green tea extract (GTE) on the quality of bread by instrumental analysis and sensory evaluation. Food Research International, 40(4), 470-479. https://doi.org/10.1016/j.foodres.2006.07.007

Wang, R., Zhou, W., Yu, H. H., \& Chow, W. F. (2006). Effects of green tea extract on the quality of bread made from unfrozen and frozen dough processes. Journal of the Science of Food and Agriculture, 86(6), 857-864. https://doi.org/10.1002/jsfa.2423

Zhang, J., \& Kashket, S. (1998). Inhibition of Salivary Amylase by Black and Green Teas and Their Effects on the Intraoral Hydrolysis of Starch. Caries Research, 32(3), 233-238. https://doi.org/10.1159/000016458

Zhou, Y., Wang, D., Wan, X., Zhang, L., Du, X., \& Hu, W. (2009). Effect of tea polysaccharide addition on the properties of bread made from two flours. Journal of Food Processing and Preservation, 33(6), 798-813. https://doi.org/10.1111/j.1745-4549.2008.00312.x 